\title{
EFFECTIVENESS OF REMOVAL OF HUMIC SUBSTANCES AND HEAVY METALS FROM LANDFILL LEACHATES DURING THEIR PRETREATMENT PROCESS IN THE SBR REACTOR
}

\author{
EFEKTYWNOŚĆ USUWANIA SUBSTANCJI HUMUSOWYCH \\ ORAZ METALI CIĘŻKICH Z ODCIEKÓW SKŁADOWISKOWYCH \\ PODCZAS ICH PODCZYSZCZANIA W REAKTORZE SBR
}

\begin{abstract}
In the paper the removal efficiency of heavy metals as well as humic compounds, in the treatment of leachate mixed with municipal waste in a sequencing batch reactor was studied. Also, the accumulation of those metals in the activated sludge was examined. It has been shown that the removal efficiency of contamination with

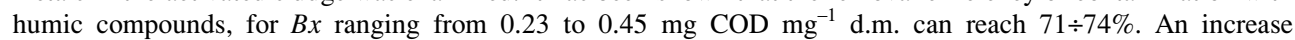
in the concentrations of heavy metals in the activated sludge was recorded for $B x$ in the range $0.23 \div 1.64 \mathrm{mg} \mathrm{COD} \mathrm{mg}^{-1} \mathrm{~d} . \mathrm{m}$. The amount of heavy metals in the effluent of the SBR in carrying out the process at $B x=0.23 \div 0.96 \mathrm{mg} \mathrm{COD} \mathrm{mg}^{-1} \mathrm{~d} . \mathrm{m}$. does not limit their discharge into water and sewer system.
\end{abstract}

Keywords: activated sludge, heavy metals, humic compounds, leachate, municipal landfills, sewage, treatment, waste

Landfill leachate from wastes other than inert or hazardous poses major sanitary risks to the land and water environment. Leachate begins as rainfall which is produced during landfill operation. Its generation rate is estimated to be $0.415 \div 0.658 \mathrm{dm}^{3} / \mathrm{m}^{2}$ day [1]. Leachate percolates through the landfill bed and extracts soluble organic and mineral fractions as well as saprotrophic and pathogenic microorganisms present in the waste. The amount of leachate depends mostly on waste deposit management, landfill age, waste type and fragmentation as well as the quantity of infiltrating water and the season (with the greatest amounts of leachate being recorded between September and April and the smallest amounts between May and October), hydrological conditions in the landfill and the vegetation type overgrowing the landfill following site rehabilitation [2-4].

The physicochemical composition of leachate varies widely. Its constituents may derive from solid or liquid components dissolved in the water or may be indirect products of biodegradation processes. Concentrations of heavy metals recorded in landfill are

\footnotetext{
${ }^{1}$ Faculty of Environmental Engineering, Warsaw University of Technology, ul. Nowowiejska 20, 00-653 Warszawa, Poland, email: miroslaw.szydlowski@is.pw.edu.pl
} 
diversified. The content of iron in USA is $55 \div 5500 \mathrm{~g} \mathrm{Fe} \mathrm{m}{ }^{-3}$ (in Poland: $0.64 \div 950 \mathrm{~g} \mathrm{Fe} \mathrm{m}^{-3}$ ), nickel in USA $0.01 \div 0.65 \mathrm{~g} \mathrm{Ni} \mathrm{m}^{-3}$ (in Poland: $0.01 \div 1.19 \mathrm{~g} \mathrm{Ni} \mathrm{m}^{-3}$ ), chromium in USA $0.053 \div 1.90 \mathrm{~g} \mathrm{Cr} \mathrm{m}^{-3}$ (in Poland: $0.00 \div 1.38 \mathrm{~g} \mathrm{Cr} \mathrm{m}^{-3}$ ), zinc in USA $0.5 \div 1000 \mathrm{~g} \mathrm{Zn} \mathrm{m}^{-3}$ (in Poland: $0.14 \div 21.5 \mathrm{~g} \mathrm{Zn} \mathrm{m}^{-3}$ ), copper in USA $0.024 \div 9.90 \mathrm{~g} \mathrm{Cu} \mathrm{m}^{-3}$ (in Poland: $0.015 \div 3.52 \mathrm{~g} \mathrm{Cu} \mathrm{m}^{-3}$ ), and lead in USA $0.054 \div 5.0 \mathrm{~g} \mathrm{~Pb} \mathrm{~m}^{-3}$ (Poland: $<0.01 \div 0.43 \mathrm{~g} \mathrm{~Pb} \mathrm{~m}^{-3}$ ) [2]. Similar content values of heavy metals are observed in urban wastewater. Their concentrations are considerably higher in some industrial wastewaters and deposits. A potential increase in metal concentrations in leachate can be caused by unauthorised deposition of industrial wastes in municipal landfills [4].

Landfill leachate can also contain alkyl aromatic hydrocarbons $\left(0.02 \div 1 \mu \mathrm{g} \mathrm{dm}^{-3}\right)$, mineral oils $\left(0.1 \div 3 \mathrm{~g} \mathrm{~m}^{-3}\right)$, phenols $\left(0.001 \div 1 \mathrm{~g} \mathrm{~m}^{-3}\right)$ [1], organochlorine compounds, pesticides, fulvic and humic acids, phthalates, aliphatic and aromatic carboxylic acids, naphthalene, aromatic nitric acids, phosphoric esters, higher-order alcohols, considerably smaller quantities of PAHs, PCBs, chlorinated dioxins and furans [5]. A very high amount of organic compounds derived from the first, acidic phase of anaerobic waste degradation, such as volatile fatty acids, low-molecular aldehydes, thiols, simple organic acids and amines, are recorded in leachate in the initial stage of landfill operation. Humic compounds, chiefly humic acids whose contribution in all organic contaminants exceeds $60 \%$ and increases together with a landfill age dominate in leachate from old landfills [6].

Chemical compounds and microorganisms posing sanitary and health risks must be removed to control the detrimental influence of landfill leachate on the environment. In order to treat landfill leachate, it is recirculated on site, removed to the wastewater system, treated together with municipal wastewater in treatment plants, treated separately in on-site treatment plants using mechanical, chemical, physicochemical and biological methods or combined systems of these methods. The efficiency of biological methods mostly depends on the chemical composition of leachate, including the concentration of organic compounds and their susceptibility to degradation defined by the $\mathrm{BOD}_{5} / \mathrm{COD}$ or $\mathrm{COD} / \mathrm{BOD}_{5}$ ratio, concentrations of nitrogen and phosphorus compounds and heavy metals. Landfill age impacts their content in landfill leachate. Biological methods are mostly useful in treating leachate from young landfills in which organic compounds occur as easily biodegradable compounds. Classical methods of activated sludge and biological deposits do not guarantee a full removal of chemical and biological contaminants from leachate even when used to treat leachate from young landfills. Therefore, much attention has been paid in recent years to the activated sludge method in sequencing batch reactors (SBRs). One of the advantages of SBRs is that technological parameters such as the duration of individual stages, cycle length and the waste supply method can be modified during operation [7]. SBRs are also easy to operate, their sensitivity to toxic substances is low, the quality of purified wastewater is high, energy consumption is optimal and their surface is small in comparison with continuous flow reactors.

\section{Samples of leachates}

Leachate delivered through a drainage system to a collection sump was used in the study. The sump is located near a landfill containing waste other than inert or hazardous, so-called municipal waste, in the south-western part of the town of Otwock. The landfill serves to deposit municipal waste with a high content of biodegradable organic substance 
(above $20 \mathrm{Mg} / \mathrm{d}$ ). It has been in operation since 1998 and will be in use until 2012. The projected landfill volume is $12 \cdot 10^{5} \mathrm{Mg} ; 2.7 \cdot 10^{5} \mathrm{Mg}$ has been used to date. The substrate is lined with a PEHD (polyethylene high density) $2 \mathrm{~mm}$ geomembrane. Waste is stored in quarters in plots with a thickness of 1.5-2 m. Insulating layers are $0.15 \mathrm{~m}$ thick. Leachate waters, the quantity of landfill gas and the contamination of surface and groundwaters near the landfill are monitored at the landfill.

The COD in the landfill was $3080 \mathrm{mg} \mathrm{O}_{2} \mathrm{dm}^{-3}$, total organic carbon content of $133 \div 1661 \mathrm{mg} \mathrm{C} / \mathrm{dm}^{3}, \mathrm{BOD}_{5} / \mathrm{COD}-0.092 \div 0.475, \mathrm{SO}_{4}{ }^{2-}-58 \div 357 \mathrm{mg} \mathrm{SO}{ }_{4}{ }^{2-} / \mathrm{dm}^{3}, \mathrm{SO}_{4}{ }^{2-} / \mathrm{Cl}^{-}$ - $0.026 \div 0.131,0.014 \div 0.428 \mathrm{mg} \mathrm{Cu} / \mathrm{dm}^{3}, 0.096 \div 6.943 \mathrm{mg} \mathrm{Zn} / \mathrm{dm}^{3}, 0.049 \div 0.526 \mathrm{mg} \mathrm{Pb} / \mathrm{dm}^{3}$, $0.003 \div 0.049 \mathrm{mg} \mathrm{Cd} / \mathrm{dm}^{3}, 0.038 \div 0.720 \mathrm{mg} \mathrm{Cr} / \mathrm{dm}^{3}, 0.001 \div 0.006 \mathrm{mg} \mathrm{Hg} / \mathrm{dm}^{3}$, conductivity $7.4 \div 22.1 \mathrm{mS} / \mathrm{cm}$ and $\mathrm{pH} 7.2 \div 7.7[8]$.

\section{Leachate treatment process}

Leachate was treated in a $6.9-\mathrm{dm}^{3}$ SBR equipped with a mixer and a diffused aeration system which guarantees the oxygen concentration of $2 \mathrm{mg} \mathrm{O}_{2} \mathrm{dm}^{-3}$ in aerobic conditions of the cycle. Activated sludge from a municipal treatment plant in Piaseczno near Warsaw was used to inoculate the SBR. The sludge concentration in the reactor was maintained at $3 \div 4 \mathrm{~g} \mathrm{dm}^{-3}$ in relation to the reactor's total volume. The content of volatile suspended solids in the sludge was $67 \%$ and mineral suspended solids $33 \%$ on average. The hydraulic retention time (HRT) was 16 hours for the organic contaminant loading $(B x)$ in the sludge ranging from 0.23 to $1.64 \mathrm{mg} \mathrm{COD} / \mathrm{mg} \mathrm{dm}$, obtained by a percentage increase in the leachate contribution $(1,3,5,10,15,20$ and 30\%) in the mixture with synthetic waste prepared according to the recipe by Klimiuk and Wojnowska-Baryla [9]. Three eight-hour cycles per day were used in the system. Each cycle consisted of a 45-minute filling phase, a 30-minute mixing phase, a 130-minute aeration phase, a 45-minute mixing phase, a 110-minute aeration phase, a 90-minute sedimentation phase and a 30-minute decantation phase (including 25 minutes of decantation and 5 minutes of idle phase). These parameters were determined experimentally in monitoring studies. Values describing the waste were controlled a number of times during the cycle (variable aerobic conditions). The SBR operated at room temperature $\left(20 \div 22^{\circ} \mathrm{C}\right)$ over a period of nine months. Control studies of the process in the range given below were conducted after a two-week period of the duration of the process after changing $B x$.

\section{Methods}

Concentrations of humic substances in the influent to and the effluent from the reactor were determined with the colorimetric method after extraction with isoamyl alcohol according to BN-90-9567-18/08 [10]. The content of heavy metals was determined using atomic absorption spectroscopy (AAS) with a Solar 919 spectrometer with initial mineralization in strong acids according to PN-ISO-8288 2002 [11].

\section{Results}

\section{Efficiency of humic substance removal}

Efficiency values of removing humic substances during the leachate treatment for different $B x$ values are given in Table 1 . The results show that the process efficiency was ca 
$70 \%$ for $B x$ ranging from 0.23 to $0.45 \mathrm{mg} \mathrm{COD} \mathrm{mg}^{-1}$ d.m., which corresponded to the concentrations of these substances in the influent to the reactor in the range 29.1 and $121 \mathrm{mg} \mathrm{dm}^{-3}$. A considerable drop in the removal efficiency of humic substances, down to $63 \%$ and $54 \%$, was recorded for loadings ranging from 0.96 to $1.64 \mathrm{mg} \mathrm{COD} \mathrm{mg}^{-1}$ d.m., for which the amount in the influent was $308 \div 830 \mathrm{mg} \mathrm{dm}^{-3}$.

Results of a quantitative analysis of humic substances during leachate treatment in an SBR

Table 1 depending on the contaminant sludge loading $(B x)$

\begin{tabular}{|c|c|c|c|c|}
\hline \multirow{2}{*}{$\begin{array}{c}\text { Leachate in the } \\
\text { synthetic waste } \\
\text { mix [\%] }\end{array}$} & \multirow{2}{*}{$\begin{array}{c}\text { Impurities sludge } \\
\text { loading }(\boldsymbol{B} \boldsymbol{x})\end{array}$} & \multicolumn{2}{|c|}{$\begin{array}{c}\text { Concentration of humic } \\
\text { substances }\left[\mathbf{m g} / \mathbf{d m}^{\mathbf{3}}\right]\end{array}$} & \multirow{2}{*}{ Removal [\%] } \\
\cline { 3 - 4 } & [mg COD/mg d.m.] & Inflow & Outflow & \\
\hline 1 & 0.23 & 29.1 & 7.90 & 73 \\
\hline 3 & 0.34 & 31.5 & 9.20 & 71 \\
\hline 5 & 0.40 & 46.7 & 14.6 & 69 \\
\hline 10 & 0.45 & 121 & 33.3 & 72 \\
\hline 20 & 0.96 & 308 & 115 & 63 \\
\hline 30 & 1.64 & 830 & 380 & 54 \\
\hline
\end{tabular}

\section{Efficiency of heavy metal removal}

Efficiency values of removing heavy metals during the leachate treatment and their accumulation in the sludge are given in Table 2 . The analysis shows that zinc was removed in $53 \div 20 \%$ only for $B x 0.23 \div 0.34 \mathrm{mg} \mathrm{COD} \mathrm{mg}^{-1}$ d.m., respectively. Zinc concentration was then $0.620 \div 0.512 \mathrm{mg} \mathrm{Zn} \mathrm{dm}^{-3}$ in the influent and $0.292 \div 0.411 \mathrm{mg} \mathrm{Zn} \mathrm{dm}^{-3}$ in the effluent. An increase in the contaminant sludge loading up to $0.40 \mathrm{mg} \mathrm{COD} \mathrm{mg}{ }^{-1} \mathrm{~d} . \mathrm{m}$. inhibited the removal of zinc from the leachate containing municipal waste. Interestingly, its concentration increased considerably in the sludge. It ranged between 7.477 and $8.631 \mathrm{mg} \mathrm{Zn} \mathrm{g}{ }^{-1}$, for $B x=0.23 \div 0.45 \mathrm{mg} \mathrm{COD} / \mathrm{mg} \mathrm{d.m.} \mathrm{while} \mathrm{the} \mathrm{zinc} \mathrm{content} \mathrm{in} \mathrm{the}$ activated sludge dropped to $5.742 \mathrm{mg} \mathrm{Zn} \mathrm{g}^{-1}$ after the loading increased to $B x=0.96 \mathrm{mg} \mathrm{COD} \mathrm{mg}^{-1} \mathrm{~d}$.m. and to $2.225 \mathrm{mg} \mathrm{Zn} \mathrm{g}^{-1}$ for $B x=1.64 \mathrm{mg} \mathrm{COD} \mathrm{mg}^{-1} \mathrm{~d} . \mathrm{m}$.

Copper was removed efficiently for $B x=0.23 \div 0.34 \mathrm{mg}$ COD mg ${ }^{-1}$ d.m. $(100 \%$ removal) when the copper content in the influent ranged from 0.276 to $0.172 \mathrm{mg} \mathrm{Cu} \mathrm{dm}^{-3}$, respectively. Between 0.632 and $0.232 \mathrm{mg} \mathrm{Cu} \mathrm{g}^{-1}$ was accumulated in the sludge for this range of $B x$. A drop in the removal efficiency (down to 62\%) was recorded for an increase in $B x$ up to $0.40 \mathrm{mg}$ COD mg ${ }^{-1} \mathrm{~d} . \mathrm{m}$. Copper concentration in the sludge increased to $1.911 \div 1.351 \mathrm{mg} \mathrm{Cu} \mathrm{g}^{-1}$ for $B x=0.45 \div 0.96 \mathrm{mg} \mathrm{COD} \mathrm{mg}^{-1}$ d.m., respectively. The process slowed down reaching $0.142 \mathrm{mg} \mathrm{Cu} \mathrm{g}^{-1}$ for $B x=1.64 \mathrm{mg} \mathrm{COD} \mathrm{mg}^{-1} \mathrm{~d} . \mathrm{m}$.

Chromium was not recorded in the influent or the effluent for $B x$ from 0.23 to $0.40 \mathrm{mg}$

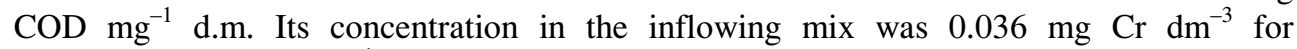
$B x=0.45 \mathrm{mg}$ COD $\mathrm{mg}^{-1} \mathrm{~d} . \mathrm{m}$. Due to a small amount of chromium, an $84 \%$ removal rate was recorded for $B x=0.96 \mathrm{mg} \mathrm{COD} \mathrm{mg}{ }^{-1} \mathrm{~d} . \mathrm{m}$. and $26 \%$ for $B x=1.64 \mathrm{mg} \mathrm{COD} \mathrm{mg}^{-1} \mathrm{~d} . \mathrm{m}$. The chromium content in the influent was then $0.514 \mathrm{mg} \mathrm{Cr} \mathrm{dm}^{-3}$ and $0.123 \mathrm{mg} \mathrm{Cr} \mathrm{dm}^{-3}$, respectively. Chromium concentration in the sludge ranged between 0.035 and $0.131 \mathrm{mg} \mathrm{Cr} \mathrm{g}^{-1}$ for the contaminant sludge loading $0.23 \div 1.64 \mathrm{mg} \mathrm{COD} \mathrm{mg}^{-1} \mathrm{~d} . \mathrm{m}$.

Nickel, lead and cadmium were not removed during leachate treatment and their small amounts accumulated in the sludge. Nickel concentration was $0.030 \div 0.500 \mathrm{mg} \mathrm{Ni} \mathrm{g}^{-1}$ for the study range of $B x$ and lead concentration was $5.575 \div 1.161 \mathrm{mg} \mathrm{Pb} \mathrm{g}^{-1}$ for 
$B x=0.40 \div 0.45 \mathrm{mg}$ COD $\mathrm{mg}^{-1}$ d.m., respectively. An increase in the cadmium content was recorded only for higher $B x$ values: $0.022 \div 0.025 \mathrm{mg} \mathrm{Cd} \mathrm{g}^{-1}$ for Bx $0.40 \div 1.64 \mathrm{mg} \mathrm{COD} \mathrm{mg}^{-1}$ d.m.

Table 2

Results of a quantitative analysis of metals during leachate treatment in an SBR depending on the sludge loading $(B x)$

\begin{tabular}{|c|c|c|c|c|c|c|c|c|}
\hline \multirow{4}{*}{ Determination } & \multirow{4}{*}{ Sample type } & \multirow{4}{*}{ Unit } & \multicolumn{6}{|c|}{ Impurities sludge loading [mg COD mg ${ }^{-1}$ d.m.] } \\
\hline & & & 0.23 & 0.34 & 0.40 & 0.45 & 0.96 & 1.64 \\
\hline & & & \multicolumn{6}{|c|}{ Leachate in the synthetic waste mix [\%] } \\
\hline & & & 1 & 3 & 5 & 10 & 20 & 30 \\
\hline \multirow{5}{*}{ Zinc } & leachate & \multirow{3}{*}[\mathrm{mg}\mathrm{dm}^{-3}]{} & 1.124 & 1.457 & 1.816 & 1.266 & 1.314 & 1.272 \\
\hline & inflow & & 0.620 & 0.512 & 0.440 & 0.533 & 0.526 & 0.588 \\
\hline & outflow & & 0.292 & 0.411 & 0.948 & 0.577 & 1.231 & 2.004 \\
\hline & removal & {$[\%]$} & 53 & 20 & 0 & 0 & 0 & 0 \\
\hline & sludge & {$\left[\mathrm{mg} \mathrm{g}^{-1}\right]$} & 7.477 & 7.918 & 8.631 & 8.150 & 5.742 & 2.225 \\
\hline \multirow{5}{*}{ Copper } & leachate & \multirow{3}{*}[\mathrm{mg}\mathrm{dm}^{-3}]{} & 0.284 & 0.255 & 0.214 & 0.119 & 0.314 & 0.360 \\
\hline & inflow & & 0.276 & 0.172 & 0.138 & ni & 0.212 & 0.352 \\
\hline & outflow & & ni & ni & 0.053 & 0.082 & 0.322 & 0.592 \\
\hline & removal & {$[\%]$} & 100 & 100 & 62 & 0 & 0 & 0 \\
\hline & sludge & {$[\mathrm{mg} / \mathrm{g}]$} & 0.632 & 0.412 & 0.232 & 1.911 & 1.351 & 0.142 \\
\hline \multirow{5}{*}{ Nickel } & leachate & \multirow{3}{*}[\mathrm{mg}\mathrm{dm}^{-3}]{} & 0.492 & 0.361 & 0.144 & 0.283 & 0.447 & 0.992 \\
\hline & inflow & & 0.052 & 0.060 & 0.072 & ni & 0.053 & 0.604 \\
\hline & outflow & & 0.088 & 0.075 & 0.068 & ni & 0.092 & 0.105 \\
\hline & removal & {$[\%]$} & 0 & 0 & 6 & 0 & 0 & 84 \\
\hline & sludge & {$\left[\mathrm{mg} \mathrm{g}^{-1}\right]$} & 0.036 & 0.030 & 0.034 & 0.041 & 0.036 & 0.050 \\
\hline \multirow{5}{*}{ Lead } & leachate & \multirow{3}{*}[\mathrm{mg}\mathrm{dm}^{-3}]{} & ni & 0.312 & 0.776 & 0.190 & 0.468 & 0.356 \\
\hline & inflow & & ni & ni & 0.362 & 0.098 & 0.347 & 0.320 \\
\hline & outflow & & ni & ni & 0.476 & 0.135 & 0.462 & 0.428 \\
\hline & removal & [\%] & 0 & 0 & 0 & 0 & 0 & 0 \\
\hline & sludge & {$\left[\mathrm{mg} \mathrm{g}^{-1}\right]$} & ni & ni & 5.575 & 1.161 & 0.583 & 0.125 \\
\hline \multirow{5}{*}{ Cadmium } & leachate & \multirow{3}{*}[\mathrm{mg}\mathrm{dm}^{-3}]{} & ni & 0.034 & 0.056 & 0.021 & 0.064 & 0.116 \\
\hline & inflow & & ni & ni & 0.038 & 0.013 & 0.048 & 0.096 \\
\hline & outflow & & ni & ni & 0.028 & 0.013 & 0.041 & 0.130 \\
\hline & removal & {$[\%]$} & 0 & 0 & 26 & 0 & 15 & 0 \\
\hline & sludge & {$\left[\mathrm{mg} \mathrm{g}^{-1}\right]$} & ni & ni & 0.024 & 0.025 & 0.022 & 0.024 \\
\hline \multirow{5}{*}{ Chromium } & leachate & \multirow{3}{*}[\mathrm{mg}\mathrm{dm}^{-3}]{} & ni & 0.231 & 0.252 & 0.710 & 0.627 & 0.148 \\
\hline & inflow & & ni & ni & ni & 0.036 & 0.514 & 0.123 \\
\hline & outflow & & ni & ni & ni & 0.082 & 0.084 & 0.092 \\
\hline & removal & {$[\%]$} & 0 & 0 & 0 & 0 & 84 & 26 \\
\hline & sludge & {$\left[\mathrm{mg} \mathrm{g}^{-1}\right]$} & 0.077 & 0.042 & 0.035 & 0.131 & 0.076 & 0.050 \\
\hline
\end{tabular}

ni - not indicated

\section{Summary}

Results of the investigations have shown that the removal efficiency of copper was high for $B x=0.23 \div 0.34 \mathrm{mg}$ COD mg ${ }^{-1}$ d.m. Zinc removal was less efficient for this $B x$ range. It was $53 \%$ for $B x=0.23$ and decreased to $20 \%$ for $B x=0.34$. Both copper and zinc as well as lead and chromium accumulated in the activated sludge for $B x=0.23 \div 0.45 \mathrm{mg} \mathrm{COD} \mathrm{mg}{ }^{-1} \mathrm{~d} . \mathrm{m}$. and were eluted when the critical values were exceeded. Nickel, cadmium and lead were not removed during the leachate treatment and an increase 
in their concentrations was small: their content in the activated sludge remained almost constant while chromium was removed for $B x$ ranging from 0.96 to $1.64 \mathrm{mg} \mathrm{COD} \mathrm{mg}^{-1} \mathrm{~d} . \mathrm{m}$.

A leachate treatment technology that is environmentally safe must aim to estimate not only the removal efficiency of contaminants expressed by such general indicators as COD and the content of nitrogen and phosphorus forms but also of specific contaminants that may adversely affect water biocenoses. Importantly, these include heavy metals. Their quantities in the leachate varied. The highest content was recorded for zinc. Its concentration in the leachate ranged between 1.124 and $1.816 \mathrm{mg} \mathrm{Zn} \mathrm{dm}^{-3}$. The lowest content was recorded for cadmium and was $0.021 \div 0.116 \mathrm{mg} \mathrm{Cd} \mathrm{dm}^{-3}$. The content of copper was $0.119 \div 0.360 \mathrm{mg}$ $\mathrm{Cu} \mathrm{dm}^{-3}$, nickel $-0.144 \div 0.992 \mathrm{mg} \mathrm{Ni} \mathrm{dm}^{-3}$, lead $-0.190 \div 0.776 \mathrm{mg} \mathrm{Pb} \mathrm{dm}^{-3}$, and chromium $0.148 \div 0.710 \mathrm{mg} \mathrm{Cr} \mathrm{dm}^{-3}$. The content of metals in the leachate did not exceed values recorded in other leachate from municipal waste landfills in Poland and worldwide [2, 12-19].

The investigations have shown that metals occurring in the leachate accumulated differently in the sludge. This depended on $B x$ values. Quantities of $\mathrm{Zn}, \mathrm{Pb}$ and $\mathrm{Cd}$ accumulated in the sludge positively corresponded with their quantities recorded in the leachate $\left(\mathrm{r}_{\mathrm{XY}}=0.39 \div 0.80\right)$, reaching the following values: $5.742 \div 8.631 \mathrm{mg} \mathrm{Zn} \mathrm{g}$, $1.161 \div 5.575 \mathrm{mg} \quad \mathrm{Pb} \quad \mathrm{g}^{-1}, \quad 0.030 \div 0.500 \quad \mathrm{mg} \quad \mathrm{Ni} \quad \mathrm{g}^{-1}, \quad 0.035 \div 0.131 \mathrm{mg} \quad \mathrm{Cr} \quad \mathrm{g}^{-1}$, ca $0.024 \mathrm{mg} \mathrm{Cd} \mathrm{g}^{-1}$. A negative correlation $\left(\mathrm{r}_{\mathrm{XY}}=-0.57\right)$ was recorded between the amount of copper in the leachate and its amount in the sludge $\left(1.351 \div 1.911 \mathrm{mg} \mathrm{Cu} \mathrm{dm} \mathrm{gg}^{-1}\right)$. The accumulation process of $\mathrm{Cu}, \mathrm{Zn}, \mathrm{Cr}$ and $\mathrm{Pb}$ in the sludge occurred for $B x=0.23 \div 0.45 \mathrm{mg}$ COD mg ${ }^{-1} \mathrm{~d} . \mathrm{m}$. They were eluted from the sludge for $B x>0.45 \mathrm{mg}$ COD $\mathrm{mg}^{-1}$ d.m. Copper and zinc were removed for

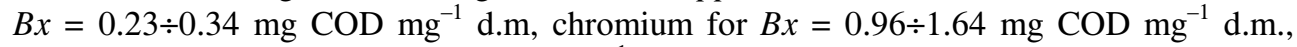

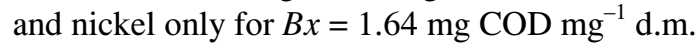

Differences recorded in the dynamics of binding and releasing these heavy metals by activated sludge are difficult to explain. This is caused both by the complexity of the chemical composition of leachate and the generic biodiversity of organisms forming the sludge biocenosis. Metal accumulation by microorganisms occurs in ways dependent on metabolism (biosorption) and independent of it. Biosorption is associated with the occurrence of groups binding metals on the cell surface and within membrane proteins. These include sulfhydryl, carboxyl, hydroxyl as well as amide and phosphate groups that play an important role in bacterial biosorption. The interaction between a metal and a function group depends on the type of binding between them. As well as adsorption, precipitation or crystallization occur on the surface of or near the cell. Some metals are retained within the cell wall or bound by extracellular polymers. Metal accumulation takes place by transport systems of mono- or divalent metals or as a response to the transmembranous electrochemical potential generated by membrane ATP-ases. This allows for a level of metal reception higher than that resulting only from the processes of extracellular adsorption [20]. Chang et al believe that adsorption processes, ion exchange, chemical binding and precipitation play a major role in removing metals from solutions by microorganisms. Metals can also be used as an acceptor of electrons and can be deposited within the cell wall or the membrane [20].

According to these authors, $23 \mathrm{mg} \mathrm{Cu} / \mathrm{g} \mathrm{d} . \mathrm{m}$. is adsorbed by Pseudomonas aeruginosa PU21, $300 \mathrm{mg} \mathrm{Cu} \mathrm{g}^{-1}$ d.m. by Zooglea ramigera; $58 \mathrm{mg} \mathrm{Cd} \mathrm{g}^{-1}$ d.m. by Pseudomonas

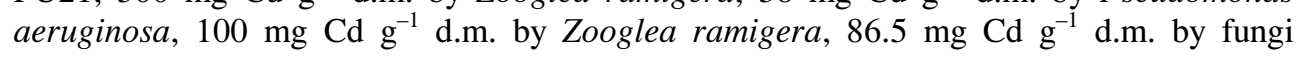


Fusarium flocciferum; $110 \quad \mathrm{mg} \quad \mathrm{Pb}^{-1}$ d.m. by Pseudomonas aeruginosa,

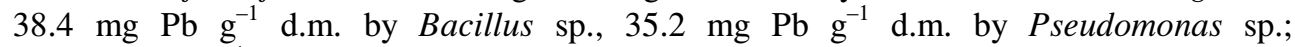
$400 \mathrm{mg} \mathrm{Hg} \mathrm{g}^{-1} \mathrm{~d}$.m. by Pseudomonas aeruginosa. Nickel is adsorbed by the fungus Fusarium flocciferum to the amount of $21.1 \mathrm{mg} \mathrm{Ni} \mathrm{g}^{-1} \mathrm{~d} . \mathrm{m}$., while the efficiency of the adsorption of lead, cadmium, copper, zinc and uranium by fungi of the genus Rhizopus is $25 \%$. The accumulation efficiency of lead, copper and zinc was high in the activated sludge formed by a multi-generic culture of micro-organisms while the accumulation efficiency of cadmium, nickel and manganese was considerably lower [20].

According to Brown and Lester and Chang et al [20], the occurrence of microorganisms producing extracellular polymers (polysaccharides, proteins, nucleic acids), metal-binding proteins, the initial metal concentration, $\mathrm{pH}$ and the specific composition of micro-organisms in relation to metals present in the waste impacts the adsorption of metals by activated sludge. The removal of heavy metals from waste by the mycoflora occurs by binding metals by chelate formation, intracellular production of specific metal-binding substances, binding in the form of polyphosphates and increased production of melanin, active transport of metals outside the cell, enzymatic ion transformation, production of vacuoles in which metal ions are accumulated and inhibited, and passive excretion of ions from the cell.

A comparison of the content of heavy metals in the activated sludge and the values permitted for land rehabilitation for agricultural and non-agricultural purposes and land adjustment for specific purposes, referred to in the Regulation of the Minister of the Environment of the $1^{\text {st }}$ August 2002 on the municipal waste sludge, shows that the activated sludge in the leachate treatment process conducted at $B x=0.23 \div 0.96 \mathrm{mg} \mathrm{COD} \mathrm{mg}^{-1} \mathrm{~d} . \mathrm{m}$. may not be used due to a high content of zinc $\left(5742 \div 8631 \mathrm{mg} \mathrm{Zn} \mathrm{kg}^{-1}\right)$. The content of lead $\left(5575 \mathrm{mg} \mathrm{Pb} \mathrm{kg}^{-1}\right.$ ) for $B x=0.40 \mathrm{mg} \mathrm{COD} \mathrm{mg}{ }^{-1} \mathrm{~d} . \mathrm{m}$. also exceeds the permissible value. A comparison of heavy metal values in the effluent from the reactor with the highest permissible values of contaminant indicators for treated industrial waste discharged to waters, referred to in the Regulation of the Minister of the Environment of the $26^{\text {th }}$ July 2006, and to the urban sewage system, defined in the Regulation of the Minister of Construction on the implementation of responsibilities of suppliers of industrial waste and conditions of waste discharge to sewage systems of the $14^{\text {th }}$ July 2006 , shows that the leachate can be discharged to waters and urban sewage systems after it is treated

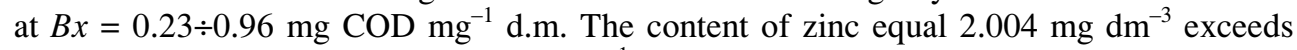
permitted values at $B x=1.64 \mathrm{mg} \mathrm{COD} \mathrm{mg}^{-1} \mathrm{~d} . \mathrm{m}$.

\section{Conclusions}

The removal efficiency of contamination with organic compounds, including humic compounds, in the treatment of leachate mixed with municipal waste in a sequencing batch reactor operating in three eight-hour cycles per day, consisting of a 45-minute filling phase, a 30-minute mixing phase, a 130-minute aeration phase, a 45-minute mixing phase, a 110-minute aeration phase, a 90-minute sedimentation phase and a 30-minute decantation phase, at the HRT $=16$ hours and the activated sludge concentration $3 \div 4 \mathrm{~g} \mathrm{dm}^{-3}$ for $B x$ ranging from 0.23 to $0.45 \mathrm{mg} \mathrm{COD} \mathrm{mg}^{-1}$ d.m. $(1 \div 10 \%$ contribution of leachate in the mix containing municipal waste) can reach $71 \div 74 \%$. A sudden decrease in the removal 
efficiency of these contaminants to 45,40 , and $15 \%$ was observed for $B x 0.69,0.96$ and $1.64 \mathrm{mg} \mathrm{COD} \mathrm{mg}^{-1} \mathrm{~d}$.m. (15, 20 and $30 \%$ of the leachate), respectively.

An increase in the concentrations of heavy metals to $5.742 \div 8.631 \mathrm{mg} \mathrm{Zn} \mathrm{g}^{-1}$, $1.161 \div 5.575 \mathrm{mg} \quad \mathrm{Pb} \quad \mathrm{g}^{-1}, \quad 0.030 \div 0.500 \quad \mathrm{mg} \quad \mathrm{Ni} \quad \mathrm{g}^{-1}, \quad 0.035 \div 0.131 \mathrm{mg} \quad \mathrm{Cr} \quad \mathrm{g}^{-1}$ and ca $0.024 \mathrm{mg} \mathrm{Cd} \mathrm{g}^{-1}$ in the activated sludge was recorded for $B x$ in the range $0.23 \div 1.64 \mathrm{mg}$ COD $\mathrm{mg}^{-1}$ d.m. Posttreatment activated sludge may not be used to rehabilitate soils for agricultural and non-agricultural purposes or to adjust soils for specific purposes as defined by the Regulation of the Minister of the Environment.

The amount of heavy metals in the effluent of the SBR in carrying out the process at $B x=0.23 \div 0.96 \mathrm{mg} \mathrm{COD} \mathrm{mg}{ }^{-1}$ d.m., which is in the field: Zinc - mg Zn $0.292 \div 1.231 \mathrm{dm}^{-3}$, copper - mg Cu $0.053 \div 0.322 \mathrm{dm}^{-3}$, nickel - $0.068 \div 0.092$ instant $\mathrm{dm}^{-3}$, lead $0.135 \div 0.476 \mathrm{mg} \mathrm{Pb} \mathrm{dm}{ }^{-3}$, cadmium - mg Cd $0.013 \div 0.041 \mathrm{dm}^{-3}$ chromium mg Cr $0.082 \div 0.084 \mathrm{dm}^{-3}$, does not limit their discharge into water and sewer system.

The content of heavy metals in the effluent from the SBR for $B x=0.23 \div 0.96 \mathrm{mg}$ COD $\mathrm{mg}^{-1}$ d.m., was in the following range: zinc -

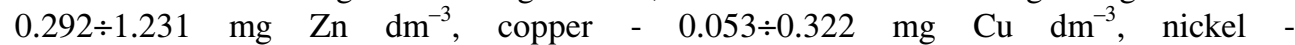

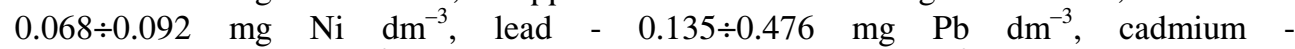
$0.013 \div 0.041 \mathrm{mg} \mathrm{Cd} \mathrm{dm}{ }^{-3}$, chromium $-0.082 \div 0.084 \mathrm{mg} \mathrm{Cr} \mathrm{dm}^{-3}$. The effluent may be discharged into waters and urban sewage systems.

\section{References}

[1] Zadroga B, Olańczuk-Neyman K. Ochrona i rekultywacja podłoża gruntowego. Gdańsk: Wyd Politechniki Gdańskiej; 2001.

[2] Szyc J. Odcieki ze składowisk odpadów komunalnych. Warszawa: Instytut Ochrony Środowiska; 2003.

[3] Surmacz-Górska J. Degradacja związków organicznych zawartych w odciekach z wysypisk. Monografie Komitetu Inżynierii Środowiska PAN; Lublin: 2001.

[4] Rosik-Dulewska C. Podstawy gospodarki odpadami. Warszawa: Wyd Nauk PWN; 2006.

[5] Wenzel A, Gahr A, Niessner R. TOC-removal and degradation of pollutants in the leachate using a thin-film photoreactor. Water Res. 1999;33:937-946.

[6] Monje-Ramirez I, Orta de Velasquez MT. Removal and transformation of recalcitrant organic matter from stabilized saline landfill leachates by coagulation-ozonation coupling processes. Water Res. 2004;38:2358-2366.

[7] Ketchum LH. Design and physical features of sequencing bath reactors. Water Sci Techn. 1997;35:11-18.

[8] Grabińska-Łoniewska A, Korniłłowicz-Kowalska T, Wardzyńska G, Boryń K. Occurrence of fungi in water distribution system. Polish J Environ Stud. 2007;16:539-547.

[9] Klimiuk E, Wojnowska-Baryła I. The influence of hydraulic retention time on the effectiveness of phosphate compound removal in the Phoredox System. Zeszyty Naukowe Akademii Rolniczo-Technicznej w Olsztynie (Acta Academiae Agriculturae ac technical olstensis). 1996;21:21-40.

[10] BN-90-9567-18/08 Determination of humic acids by colorimetry method.

[11] PN-ISO-8288 2002. Jakość wody. Oznaczanie kobaltu, niklu, miedzi, cynku, kadmu i ołowiu. Metody atomowej spektrometrii absorpcyjnej z atomizacją w płomieniu.

[12] Sletten RS, Benjamin MM, Horng JJ, Ferguson JF. Physical-chemical treatment of landfill leachate for metals removal. Water Res. 1995;29:2376-2386.

[13] Urase T, Salequzzaman M, Kobayashi S, Matsuo T, Yamamoto T, Yamamoto K, Suzuki N. Effect of high concentration of organic and inorganic matters it landfill leachate on the treatment of heavy metals in very low concentration level. Water Sci Techn. 1997;36:349-356.

[14] White C, Gadd GM. An internal sedimentation bioreactor for laboratory-scale removal of toxic metals from soil leachates using biogenic sulphide precipitation. J Industrial Microbiol Biotechnol. 1997; 18:414-421.

[15] Jensen D, Christensen TH. Colloidal and dissolved metals in leachates from four Danish landfills. Water Res. 1999;33:2139-2147. 
[16] Calace N, Liberatori A, Petronio BM, Pietroletti M. Characteristics of different molecular weight fractions of organic matter in landfill leachate and their role in soil sorption of heavy metals. Environ Pollution. 2001;113:331-339.

[17] Kalyuzhnyi S, Gladchenko M, Epov A, Appanna V. Removal of chemical oxygen demand, nitrogen, and heavy metals using a sequenced anaerobic-aerobic treatment of landfill leachates at $10-30^{\circ} \mathrm{C}$. App. Biochem Biotechnol. 2003;109:181-196.

[18] Ettler V, Matura M, Mihaljevič M, Bezdička P. Metal speciation and attenuation in stream waters and sediments contaminated by landfill leachate. Environl Geology. 2005;49:610-619.

[19] Oygard JK, Gjengedal E, Royset O. Size charge fractionation of metals in municipal solid waste landfill leachate. Water Res. 2007;41(1):47-54.

[20] Karwowska E. Usuwanie wybranych metali ciężkich ze ścieków przy zastosowaniu osadu czynnego. Warszawa: WN PW; 2000.

\title{
EFEKTYWNOŚĆ USUWANIA SUBSTANCJI HUMUSOWYCH ORAZ METALI CIĘŻKICH Z ODCIEKÓW SKŁADOWISKOWYCH PODCZAS ICH PODCZYSZCZANIA W REAKTORZE SBR
}

\author{
Wydział Inżynierii Środowiska, Politechnika Warszawska
}

\begin{abstract}
Abstrakt: W pracy badano efektywność usuwania metali ciężkich oraz substancji humusowych podczas procesu oczyszczania odcieków zmieszanych ze ściekami bytowymi w sekwencyjnym reaktorze porcjowym. Ponadto, zbadano proces akumulacji tych metali w osadzie czynnym. Stwierdzono, że efektywność usuwania zanieczyszczeń zawierających substancje humusowe osiągała $71 \div 74 \%$ przy $B x \quad$ w zakresie 0,23 $\div 0,45 \mathrm{mg}$ ChZT/mg s.m. Zwiększenie stężenia metali ciężkich w osadzie czynnym odnotowano dla $B x$ w przedziale $0,23 \div 1,64 \mathrm{mg}$ ChZT/mg s.m. Ilość metali ciężkich w odpływie z SBR podczas trwania procesu przy $B x=0,23 \div 0,96 \mathrm{mg} \mathrm{ChZT/mg} \mathrm{s.m.} \mathrm{nie} \mathrm{ogranicza} \mathrm{ich} \mathrm{odprowadzania} \mathrm{do} \mathrm{wód} \mathrm{i} \mathrm{kanalizacji} \mathrm{miejskiej.}$
\end{abstract}

Słowa kluczowe: metale ciężkie, oczyszczanie, odcieki, odpady, osad czynny, składowiska odpadów komunalnych, ścieki, związki humusowe 